RISE AND DECLINE OF ECONOMIC POLICY AS AN

AUTONOMOUS DISCIPLINE:

A CRITICAL SURVEY

Nicola Acocella

Working paper $n .123$

March 2014 


\title{
RISE AND DECLINE OF ECONOMIC POLICY AS AN AUTONOMOUS DISCIPLINE: A CRITICAL SURVEY
}

\author{
Nicola Acocella ${ }^{1}$
}

\begin{abstract}
After Smith's statement of the market virtues the process of gestation of economic policy as a consistent set of rules for public agenda has been rather slow. Until not so long ago economic policy as a discipline was confined to prescribing practical rules intended to explain technical procedures of government intervention. Economic policy as a coherent and to some extent autonomous discipline emerged in the late 1950s in Scandinavian countries, the Netherlands and Italy, when solid foundations indicating market failures and a theory about conditions for policy effectiveness and design had been developed. This paper intends to explain the reasons for its emergence, the circumstances which helped it to be taught in many Scandinavian, Dutch and Italian universities and a few other European ones, the reasons for its apparent setback and some factors that could facilitate its diffusion in the next years.
\end{abstract}

Keywords: Economic policy, welfare economics, theory of economic policy, history of economic thought

JEL codes: B00, B41, E60

\section{INTRODUCTION}

This paper studies the process through which the discipline of economic policy as a set of consistent rules for public agenda to some extent autonomous from economic analysis emerged in Scandinavian countries and the Netherlands after Adam Smith's statement of the virtues of competitive markets ${ }^{2}$. It also deals with

${ }^{1}$ Professor of Economic policy, Department of Methods and Models for Economics, Territory and Finance, MEMOTEF, Faculty of Economics, University of Rome 'La Sapienza', Via Castro Laurenziano, 9 - 00161 Roma - nicola.acocella@uniroma1.it

2 We are conscious that attribution to Smith of the naïf idea of a fully pro-market position - in particular the prevailing interpretation of the meaning of the invisible hand - is unfounded in Smith's works and has been criticized by a number of authors (e.g., Grampp, 2000; Rothschild, 2001; Roncaglia, 2005; Marglin, 2008). However, we must distinguish two different issues: the first one is whether it is appropriate to refer to the term 'invisible hand' with respect to either the letter of Smith's works (in particular in The wealth of nations) or the context where it appears; a separate issue is whether it is representative of Smith's thought as arguing in favour of the virtues of the market. Scarce recurrence of the term in Smith's works or the possible inappropriateness of the citations where Smith makes use of this term for arguing in favour of the virtues of the market (typical is the case of the home bias in Smith, 1776, Book IV, chapter 2) are founded, but refer to the first issue. We are however interested in the latter. From a substantive point of view, undoubtedly Adam Smith gives a positive assessment of the market, whose operation - in his opinion - usually tends to pursue the public good in a number of ways, especially by favouring the division of labour. In any case, we use the term 
some factors that brought the discipline to a decline - in particular as an effect of the destructive critique of a part of its 'core' - and with some recent theoretical advances that could contribute to its resurgence. The paper then devotes some space to how the discipline developed in Italy, as some such advances have recently emerged there.

Obviously, the discipline could not have emerged in the absence of a diffuse position by economists in favour of state intervention to correct or substitute markets. After Smith a stiffer line of reasoning had indeed developed in the economic discipline asserting the reasons for a 'night-watchman' state. This had been inaugurated by Bastiat (1851) and Spencer (1850) and was later prosecuted by Pareto's Cours d'économie politique (Pareto, 1896-1897), finally leading to Nozick (1974), Hayek (1960), Buchanan (1975), Tullock (1976) ${ }^{3}$. In Italy, the minimal state doctrine had a number of followers, starting with Ferrara (e.g., see Ferrara, 1859$)^{4}$ and, as said, Pareto of the Cours d'économie (Pareto, 18961897).

Over the years the 'night-watchman' position became an exception as most classical and marginalist economists tended to state a number of specific or general cases where government intervention was in order. All the same, until the 1930s there was no 'logic' (i.e., no set of general principles) for co-ordinated and consistent policy action in a market economy. Economic policy as a discipline was confined to a set of practical rules intended to assert technical procedures of government intervention, particularly in the realm of microeconomics (customs policy, price controls) and monetary theory. Theoretical contributions on the theory of international trade and the balance of payment adjustment were considered as specific parts of the economic discipline. In Italy, the contributions of Pareto's Manuel (Pareto, 1906) and Barone (1908) had left only limited (but significant, as we will see) seeds on the side of mathematical economics, welfare economics (as the logic of economic policy) and the theory of economic policy ${ }^{5}$, which were later used by the international scientific community as bricks for building economic policy as an autonomous discipline.

\footnotetext{
'invisible hand' as a metaphor of the Smithian position as well as of later theories, in particular neo-classical thinking, which has then prevailed, even if the latter are deprived of some social aspects of the working of the market that certainly were in Adam Smith. We are less interested in theories, such as the institutionalist ones, advocating government intervention in market economies.

${ }^{3}$ The different arguments put forward by Bastiat, Spencer and Pareto in support of their minimal state doctrine are reconstructed by Romani (2013). The post-World War II contributions of the same orientation can be considered as a re-appraisal of the Smithian attitude in favour of a minimal state as a consequence of comparing different institutions (Screpanti, Zamagni, 1989: 378 ), enriched by the emergence of socialist experience.

${ }^{4}$ A complete reconstruction of Ferrara's view on the principles to be jointly satisfied for justifying government intervention into the economy (general interest, necessity and advantage over private action) and on their inexistence in practically all the real cases is given by Berardi (1894).

5 In what follows I will refer to the 'theory of economic policy' as that part of the discipline of economic policy that deals with conditions for consistent and successful policy action.
} 
Until the 1930s public finance had a higher status than economic policy worldwide, as it had developed a theory of public goods and a conception of the role of the state, with important contributions by Italian and Scandinavian scholars ${ }^{6}$. A subject such as macroeconomic analysis and policy barely existed, as these only started with Keynes (1936) contribution, which however was not easily accepted in Italy and some other European countries.

In the 1930s and the following decades further essential seeds were added. On the side of the logic for government intervention in market economies, a debate involving some leading economists of the time began on the principles of government intervention, the role of distributive considerations vis-à-vis those of efficiency, the need for effective or potential compensation and the possibility of taking both efficiency and distributional aspects into consideration in order to maximise a society's economic welfare starting from individual preferences. The concept of macroeconomic market failures also emerged in addition to the microeconomic ones already stated (by Sidgwick, Marshall, Pigou, etc.). On the other side, the possibility of empirical testing of theoretical propositions as a consequence of the birth of econometrics gave the possibility of taking into account the multiple interrelations existing in an economic system for coordinating government interventions directed to a set of different targets.

These advances made it possible for an autonomous discipline to finally sprout in Scandinavian countries and the Netherlands in the 1950s. The geographical location of the fathers of the discipline was the product of a number of circumstances: not only the political trends and the social substrate prevailing in these countries, but also their full participation to the wave of theoretical innovations that had produced the slow but steady developments of the essential seeds of the discipline. Italy had been rather isolated from such developments during the Fascist phase, but in the 1950s it was ready to import theoretical advances abroad, as a result of the concurrence of specific circumstances, rather different, however, from those operating in Scandinavian countries and the Netherlands. Starting late did not prevent theorists in this country from soon borrowing the new discipline, in the 1960s and to contribute - in the years after 2005 , together with other theorists well trained in the original theory - possibly decisive advances for its re-emergence after the long decline begun in the 1970s.

The rest of the paper is organized as follows. Next section will deal with the first, non-systematic, attempts of economists within the neo-classical approach to indicate cases for government intervention. Section 3 investigates theoretical advances in the Thirties that made it possible to devise economic policy as an autonomous discipline. Section 4 discusses the foundations and articulation of economic policy in some countries of Continental Europe and its practical

\footnotetext{
${ }^{6}$ See Pantaleoni (1883), De Viti De Marco (1888), Mazzola (1890), Lindahl (1919), Wicksell (1926). According to Einaudi (1934), Italian economists' contributions made it possible for public finance to acquire a scientific status. A similar appreciation came later by Buchanan (1960) and Musgrave and Peacock (1994). Scandinavian contributions are well known, as Lindahl (1919) was originally published in German and soon reviewed in an English-speaking journal (Peck, 1921).
} 
absence in other European and non-European countries. Section 5 deals with developments of the discipline in Italy in the 1960s. Section 6 discusses some possible reasons explaining why the developments of economic policy in Scandinavia, the Netherlands and Italy had a limited impact in Europe (and elsewhere). Section 7 deals with the main theoretical objections raised against the conception of Economic policy as a consistent and autonomous discipline. Section 8 concludes.

2. ECONOMIC POLICY IN THE EARLY 1930S: A LITTLE MORE THAN A COLLECTION OF EXAMPLES OF EMPIRICAL POLICY.

Most classical writers and the marginalists had suggested cases where public intervention was in order. This had been so for Smith (1776), Ricardo (1817), Mill (1848), Marshall (1890), Walras (1874-1877, 1898). But these cases were mainly what Walras called 'examples of empirical policy' rather than consistent policy. They were certainly dictated on the basis of an analytical evaluation of the circumstances suggesting them, but were not part of a systematic and consistent assessment of the foundations and the articulation of public policy.

A systematic discipline of the foundations of government intervention (what was later called welfare economics - or became a part of social choice theory, first and implementation theory, more recently - and can be considered as the "logic of economic policy') only began to emerge towards the end of the Eighteen century. The first attempts to develop such a theory were those of Sidgwick (1883), whose treatise had economic policy as an object in its third part. Similarly, Marshall (1890) and Pigou $(1912,1920)$ had also laid down essential principles for state intervention, partly connecting it to the preferences of citizens. These had been produced not only as an almost occasional and case-by-case by-product of analytical investigations (as it was for the 'classics'), but had a systematic corpus of principles and justified a number of microeconomicy policy interventions. However, apart from their debatable foundations (utilitarianism ${ }^{7}$ ), these principles were condemned to be dormant for a long while, until the 1930s. In addition, the cases of market failures requiring public intervention had still to be studied. It is paradoxical that the general principles on which these were later asserted had already been put forward by Pareto (1906), whose principle was interpreted as supporting the virtues of markets for a long time. Some developments, as for macroeconomic market failures, had to wait for Keynes's contribution ${ }^{8}$, even if seeds had been laid for its emergence. Especially relevant in our perspective are: the influence on Keynes of Wicksell's theory integrating the monetary and real

\footnotetext{
${ }^{7}$ On the utilitarian roots of Marshall's thought see Dardi (2010).

8 Stiglitz (1986: ch.4) first formally recognized unemployment and inflation as cases of macroeconomic market failures. Other macroeconomic failures can also be added to these, such as those deriving from low (or excessive, unsustainable) growth or external imbalances, for which we refer to Acocella (1994).
} 
sectors (Wicksell, 1898) ${ }^{9}$; the demonstration by the Stockholm School ${ }^{10}$ of how employment can be stimulated by economic policy, which originally appeared before Keynes (Ohlin, 1937) $)^{11}$.

Asymmetric information as a cause of market failures came much later (Akerlof, 1970). Finally, the issue of consistency among different policy actions, which had to become even more important as the realm of policy actions widened, had not been raised yet. This first appeared, in 1952, with Tinbergen's famous theorem in the theory of economic policy (that achieving multiple targets requires at least so many policy instruments) ${ }^{12}$. Awareness of interdependence among economic variables certainly existed, especially after the emergence of the theory of general equilibrium, but to prove the significance of that point statistically for policy had to wait for the birth of econometrics.

3. The DeVelopments of the 30S: THE SEeds FOR the BIRTH OF ECONOMIC POLICY AS AN AUTONOMOUS DISCIPLINE.

This situation rapidly changed after WWII as a result of four developments in the theory that had emerged in the Thirties.

First, the development of the 'new welfare economics' underlined the relevance of market failures at a micro level and contributed to the theory of justice. In particular, before WWII a large debate continuing after the war arose on basic principles of policy intervention such as that of compensation (Harrod, 1938; Hotelling, 1938; Kaldor, 1939; Hicks, 1939; Scitovsky, 1941; Little, 1949) founded on the non-utilitaritarian bases laid down by Pareto. Bergson (1938) introduced the notion of a social welfare function, but Arrow $(1950,1951)$ later showed the difficulty of arriving at such a function by starting from individual values. After the war the various market failures were investigated in a systematic way, thus offering justifications for government intervention. A summary of these advances is expressed by Kapp (1950) and Bator (1958).

Second, the advent of the Keynesian thought (Keynes, 1936), which had soon developed as the new orthodoxy, introduced a new important case of market failure and the need for government intervention.

A third factor came from the new discipline of econometrics, as a development of mathematical economics that permitted to empirically assess the values of the system's parameters and interrelations (Tinbergen, 1935, quoted by Hughes

\footnotetext{
${ }^{9}$ E.g., Laidler (1999), Hirai T. (2008), Arnon (2011).

${ }^{10}$ D. Hammarskjöld, A. Johansson, K. Kock, E. Lindahl, E. Lundberg, G. Myrdal, B. Ohlin, and I. Svennilsson were part of the School (Kærgård, Sandelin and Sæther, 2008). On this School see Jonung (1991).

11 However, Carlson, Jonung (2013) shows that there seems to have been an interaction between Keynes's and Ohlin's ideas. When Swedish economists first read the General Theory they thought that 'Keynes ideas were tracking the views already developed in Sweden' and reacted that Keynes was too 'classic' and little innovative, which made him increasingly irritated (Jonung, 2013: 2).

${ }^{12}$ See Hughes Hallett (1989) for a historical and analytical discussion.
} 
Hallett, 1989). Construction of formal models to be tested against reality introduced the idea of the need for consistency of different public policies and the possibility to check their real effectiveness. This factor played an essential role for developing the theory of economic policy. It then appears not so strange that the authors who first contributed to this theory, i.e. Jan Tinbergen and Ragnar Frisch, were among the founders of the Econometric society and the Journal 'Econometrica' in the early 1930s. Tinbergen built the first econometric models of the Dutch and the US economies in 1936 and 1939, respectively (Hughes Hallett, 1989). From this activity the theory of economic policy easily followed. In fact, Tinbergen $(1952,1956)$ developed a theory in terms of 'fixed targets', suggesting that a number of instruments at least equal to that of targets should be available to the policymaker in order for him to be able to exactly reach the set of target values he preferred (Tinbergen's golden rule of economic policy). Frisch (1949, 1950, 1957 ) instead stated a theory of economic policy in terms of 'flexible targets' ${ }^{\prime 3}$ and its route was later followed by Theil $(1956,1964)$ and became the general way of setting a policy problem in a 'parametric context': the policymaker, in the same vein as a household, tends to maximize his preferences, or to minimize a loss function in terms of quadratic deviations from a set of target values for the variables of interest, under the constraint of a set of equations describing the given behavior of the economic system. In the case where he has a sufficient number of instruments - as indicated by Tinbergen's golden rule - the loss function is minimized and the set of target values is reached. ${ }^{14}$

Finally, planned economies experienced high growth rates in the Thirties and the following decades, which contributed to the idea that governments could be successful in ruling economic systems, possibly even more than markets, which were hit by the Great Depression ${ }^{15}$.

\section{FOUNDATION AND ARTICULATION OF ECONOMIC POLICY IN CONTINENTAL EUROPE}

\footnotetext{
${ }^{13}$ Even if the approach followed by Frisch was different from that of Tinbergen, the latter recognized his theory was somewhat inspired by Frisch's approach (Tinbergen, 1952).

14 The Norwegian school of the theory of economic policy, founded by Frisch, had also other economists following his route: O. Aukrust, H. J. Kreyberg, B. Thalberg and, most importantly, T. Haavelmo (most of his works relevant to our topic are in Norwegian, e.g., Haavelmo, 1956, 1966) and L. Johansen (Johansen, 1977, 1978). Bent Hansen - a Danish-born economist graduated at Uppsala University - became an influential advisor to the Swedish government and professor at Stockholm (and Berkeley) and offered an independent contribution to the goals-means theory of economic policy (see Hansen, 1955; Erixon, 2011). For a rather exhaustive review of the contributions of Scandinavian and Dutch authors to the theory of economic policy refer also to Rey (1967), Hughes Hallett (1989) and Acocella, Di Bartolomeo, Hughes Hallett (2012).

15 This was one of the reasons why Frisch and Johansen thought that national economic planning managed by well-trained economists was clearly superior to the market (Kærgård, Sandelin and Sæther, 2008).
} 
These developments led to the foundation of the discipline of economic policy in part of Continental Europe, specifically in Scandinavian countries and the Netherlands.

Zeuthen (1958) was the first (and successful) attempt to offer a systematic and consistent summary of developments in welfare economics and the theory of economic policy, as cornerstones of economic policy as an autonomous discipline ${ }^{16}$. An explicit link between these two cornerstones was supplied by those economists who suggested to derive social welfare functions from official documents and statements or interviews with policymakers (Frisch $(1957,1970)^{17}$, following suggestions made by Bergson (1938), Samuelson (1947), and failing the possibility to construct them directly from individual preferences when some reasonable axioms were assumed, as shown by Arrow $(1950,1951)^{18}$.

The logic of economic policy and the theory of economic policy constituted the 'core' of what has been called the 'classical or 'normative' theory of economic policy, as they investigate, at an abstract level, some of the preconditions for existence and efficient management of public policy: i.e., cases of market failures and consistency of policy action addressing such failures. They entered the curricula of master degrees in Scandinavian universities in the 1960s and 1970s through Tinbergen (1956), Zeuthen (1958), Johansen (1977, 1978), etc. as textbooks.

Why did such a discipline - in particular the theory of economic policy - develop only in those countries of Continental Europe? This is a very difficult issue to deal with. I will try to indicate some of the relevant factors, but a more accurate map of the rise of the discipline and the factors favouring or hindering it in each country should be drawn on a country specific basis.

One might argue that development of economic policy as an autonomous normative discipline was natural for countries that had adopted (indicative) planning for their economies, even if Zeuthen had warned that the theory of economic policy was not only necessary for planned economies, but also useful for less interventionist societies, because of the need to ensure their policy choices are kept mutually consistent. In fact, 'economic policy action changing according to moods can be extremely harmful' (Zeuthen, 1958: 133 Italian tr.). Undoubtedly, complexity of economic policy and the need for coordinating the various fields of action are more acute where the goals of policy action to correct markets are more ambitious and widespread. This could rather easily explain why such a theory never developed in the United States where the dominant credo

\footnotetext{
16 The importance of this book for the development of economic policy as an autonomous discipline in Italy must be stressed, as it was translated into Italian in 1961.

${ }^{17}$ In his Nobel lecture, Frisch states some of the rules to be followed for deriving such a function - as a first stage in the process of cooperation between experts and politicians - and adds that he had a number of tests of the practical effectiveness of this procedure. The whole Institute directed by Frisch and a number of economists also abroad tried to develop such method. Here we only mention a couple of works by Dutch and French-speaking economists: Van Eijk, Sandee (1959), Kirschen, Morissens (1964).

${ }^{18}$ This topic will be discussed again in section 7 .
} 
was one of scarce public interventions, with the exception of unemployment and anti-inflationary policies ${ }^{19}$. In a similar vein one could say that this was the case also of Germany, where macroeconomic action was typically less relevant and mainly directed to an anti-inflationary target.

However, this explanation would scarcely fit the case of the United Kingdom where there was a vast array of public actions, including - in addition to macroeconomic policy - extensive recourse to public enterprises and the welfare state but neither the theory of economic policy nor the whole discipline of economic policy developed as a discipline, even if extensive contributions were made to systematic national accounting (e.g., Stone, Croft-Murray, 1959) ${ }^{20}$. The only attempt made in order to build a systematic set of logical alternatives as a guide to action was made by Meade (1951, 1955), who, however, succeeded in pursuing his target only partially, i.e. specifically with respect to international economic policy and not in more abstract and general terms ${ }^{21}$.

Nor would it explain the absence of a theory of economic policy in France, where the government played an important role in a number of fields and indicative plans were prepared for some decades after WW II. Perhaps, other factors - in addition to those of a casual nature - were relevant. So, in order to explain absence of a discipline rationalizing state intervention in countries with a large role of the state in the economy, some importance could be attributed to the general attitude toward science, e.g., positivism in Anglo-Saxon countries (as this type of epistemology denies a scientific status to normative statements), or the limited role of economists vis-à-vis politicians and bureaucrats in France. On the other hand, homogeneity of Scandinavian and Dutch societies ${ }^{22}$, relative

19 The few textbooks on economic policy published in the United States usually lacked systematic treatment of the general ends of public economic action, dealing mainly with more or less technical notions of the economic policy instruments that can be used to further specific ends (e.g., see Boulding, 1958; Norton, 1966). A partial exception is Watson (1960), which has many features of a complete textbook on economic policy, including a (short) discussion of welfare economics and market failures, but lacks any reference to the theory of economic policy.

${ }^{20}$ An explanation could be that public intervention in Britain was so obvious that there was no need to theorize it. This would however be against one of the main goals of the theory of economic policy, i.e. the need for consistency of the various policy actions. Another partial explanation of this apparent exception of Britain to host a 'school' of economic policy could be that in the 1950s and the following decade the attention of at least part of the academic left in Britain was directed to some alternative target, i.e. developing a more radical critique of the prevailing marginalist credo, as done by the Neo-Ricardians. Over time, policy attitudes towards laissez-faire and government intervention changed, suggesting to dismantle positive policy action.

${ }^{21}$ Meade's analysis deals with the use of multiple instruments to pursue various targets at the same time, in particular balance of payments equilibrium, full employment and, more generally, economic welfare.

${ }^{22}$ The very notion of a unitary Scandinavian economic policy model has been debated (Pekkarinen, 1988), but the degree of homogeneity of the Scandinavian societies - certainly within each country (see, e.g., Bjerkholt, 1998, 2005, for Norway) and to a large extent also with respect to other European countries - was and still is very high. In particular, two features common to all Scandinavian countries are incomes policy and other institutions typical of this 
weakness of groups in favour of specific interests and acceptance of the implications of a social consensus tended to facilitate a unifying approach to policymaking; in addition, an important role might have derived from existence of bodies composed by economists intermediating between politicians and bureaucrats for devising a set of consistent policies ${ }^{23}$.

Some other traits of Scandinavian (and possibly Dutch) academics should be noticed, i.e., their relatively asymmetric openness to international intellectual circuits. Living in small countries, they learnt and could speak foreign languages, really more German than English up to the second world war, but often wrote in their native language. Exchanges among the scholars of the different Scandinavian countries were guaranteed by regular Scandinavian conferences and a 'Marstrand Meeting' for Scandinavian economic researchers since 1936 and until 1985 (Kærgård, Sandelin and Sæther, 2008). ${ }^{24}$ This made it possible for developments abroad to penetrate each Scandinavian country and to spread in the region, but might also have delayed or made it difficult for some ideas introduced there to be absorbed abroad, thus impairing future developments of the discipline.

A final important factor that could explain the birth of economic policy as a discipline in Scandinavian countries is the tendency of Scandinavian economists to tune into public debate on economic policy issues, by writing in the home press and journals, participating to debates confronting them with politicians and policymakers and, sometimes, turned to politics ${ }^{25}$.

These factors raise a final issue, which is important from a methodological point of view. In trying to explain the emergence of economic policy as a discipline we have referred first to theoretical developments in the field of economic science and then to some features of the various countries and societies as well as to the nature of current political attitudes in each. This way of proceeding is necessary

particular version of capitalism (the so-called Nordic model). In so far as the Netherlands are concerned, notwithstanding existence of a similar degree of social homogeneity, one must consider that at the end of the war the Government was an uneasy coalition of different political parties (Hughes Hallett, 1989: 192).

${ }_{23}$ A Centraal Plan Bureau was instituted in the Netherlands in 1945. In Norway a Planning department was created at the Ministry of Finance in the 1950s that, together with the Statistical Bureau of Census and the Institute of Economics of the University of Oslo, constituted an 'Iron Triangle' for the build-up of economic planning in Norway (Eriksen, Hanisch and Sæther, 2008). A very detailed account of the interaction between theoretical innovations and the use of macroeconomic models for policy making, especially under the influence of Frisch, is in Bjerkholt (1998).

24 In each Scandinavian country there was a main economic national journal and national languages were the normal vehicle of expressing or discuss new ideas (Kærgård, Sandelin and Sæther, 2008). However, some of the main contributions (especially books, including the main works by Wicksell and Lindahl, and doctoral dissertations) were in German. Until 1917 more than $50 \%$ of foreign books acquired by Swedish research libraries were in German (Palson Syl, Sandelin, 2001) and only after WWI and the Nazi regime there was a deGermanisation of Swedish economics (Sandelin, 2001).

${ }^{25}$ On the Swedish experience an important source is Carlson, Jonung (2006), but this also hints at other Scandinavian countries. 
because of a certain lack of correspondence exists between developments in the economic science - which certainly have now an international span and to some extent were already so around WWII - and current policy debates in each country, as the international community of economists is to some extent separated from the public and private decision makers, interest groups, the press, other scientists and the general public in each country (Acocella, 2013). The two communities interact in a way that can be thought as being conducive to a policy model that is specifically national, with some degree of nation-wide coherence. They still do so now after a further wave of globalization, even if less so than in previous decades. In explaining the birth of economic policy as a discipline in Scandinavian countries we can thus speak of a kind of national (economic) policy model, as done by Pekkarinen (1988) in dealing with an issue central to our analysis but of a more limited content, that of Keynesianism and the framework of policy ideas prevailing in Scandinavian countries. The model 'is created out of the broad structural, cultural, social and institutional contest of each country' (Pekkarinen, 1988: 4). These factors all converged in Scandinavian countries to produce a context favourable to the birth of a discipline such as economic policy ${ }^{26}$.

\section{ECONOMIC POLICY IN ITALY SINCE THE 1960S}

In Italy economic policy was hardly taught or investigated as a discipline, at least until mid-1930s. Most Italian economists, who were usually engaged in the administration of practical policies, had followed the autarchy and corporatism credo dictated by the Fascist regime; but, being largely isolated from theoretical developments abroad, did not possess many of the instruments necessary for a systematic approach to economic policy. Trade and colonial policy and law and banking policy were its main substitute.

By mid-1930s a specific term for the discipline was finally forged: Politica economica, i.e. Economic policy (e.g., see Fontana Russo, 1935), ${ }^{27}$ although its content remained pretty much the same as before. In the early 1950 s practically only a few Italian scholars had introduced - or were about to introduce Keynesian thought in Italy, starting from G. U. Papi, A. Franchini Stappo, V. Marrama, F. Di Fenizio and F. Caffè ${ }^{28}$ Even fewer Italian scholars had studied progresses in welfare economics (Caffè in 1953 and Lombardini in 1954), ${ }^{29}$ which is apparently strange, as these were based on Paretian foundations and there

\footnotetext{
${ }^{26}$ Possibly the common cultural ascendant in Scandinavian countries of economic policy as an autonomous discipline can be traced back to Wicksell. Wicksell's socialist orientation, his support for the welfare state, his critical analysis of Pareto's maximum principle for which see Palsson Syll, Sandelin (2001), his analyses of macroeconomic failures in terms of employment and inflation are all elements having an influence on many posts of the future discipline.

$27 \mathrm{~A}$ previous text by this same author referred to trade treaties and policy (Fontana Russo, 1902).

${ }^{28}$ Papi (1953), Franchini Stappo (1955), Marrama (1961); Di Fenizio (various years).

29 Caffè (1953, 1956a); Lombardini, (1954); Caffè's translation of some essays in welfare economics (Caffè, 1956b); Caffè's translation of Zeuthen (1958) (Caffé, 1961).
} 
were academics following Pareto's method, such as L. Amoroso. ${ }^{30}$ Similarly, very few scholars had done the same thing for the theory of economic policy (Caffè, Marrama and, to some extent, Di Fenizio) ${ }^{31}$. In some cases theoretical advances abroad were introduced under the form of textbooks by Italian authors ${ }^{32}$. In other cases some Italian journals hosted either important original articles by foreign authors or their translations ${ }^{33}$. Translations of books or essays collected as books also played an important role. ${ }^{34}$ The intellectual openness of the economists mentioned was crucial also in their propensity to encourage their pupils to complete their preparation abroad, mainly in the United Kingdom and the US.

By the beginning of the 1960s in Italy there were all the premises for devising a consistent and rather autonomous set of propositions to fill the discipline of Economic policy with new stuff. The only problem was about the weights to assign to the different possible ingredients. There were two main lines along which the discipline was systematically introduced, by two scholars: Federico Caffè and Ferdinando Di Fenizio. We discuss the former only here, as his contributions seem to have been more innovative with respect to our topic.

Caffè had searched for all the possible key ingredients for conceiving economic policy as an autonomous discipline. Indeed he did so first by critically reviewing progresses in the development of welfare economics (Caffè, 1953, 1956a), then translating into Italian and editing a collection of papers on the new welfare economics and the social welfare function (Caffè, 1956b) and editing the Italian translation of Zeuthen (1958), finally publishing a textbook in two volumes on Economic policy (Caffè, 1966, 1970). A path to some extent similar to Caffe's was followed by a group of economists in Naples, led by Augusto Graziani, who wrote a book containing first foundations for public economic action, then the theory of economic policy, and finally detailed policies aiming at specific short- or long-run targets (D'Antonio, Graziani, Vinci, 1972, 1979) ${ }^{35}$.

For many years these, together with a few others were the main economic policy textbooks circulating in Italy, widely adopted in most universities. After 1990 other textbooks were written along lines similar to those of Caffè and D'Antonio,

\footnotetext{
30 Pareto had a very extensive, if lagged, impact on the academic profession abroad, in particular, for what we are interested in in this paper, not only for his welfare principle but also for laying down the tools of mathematical economics that contributed to the foundation of econometrics (Tinbergen, 1949). A number of academics such as L. Amoroso had followed his teaching only in so far as the use of mathematics for economic analysis was concerned.

${ }^{31}$ Caffè's translation of Zeuthen (1958), Marrama (1962), Di Fenizio (various years).

32 Di Fenizio (various years), Marrama (1948).

${ }^{33}$ This was the case of a number of contributions - by Frisch, Tinbergen, Theil, and, outside the proper realm of economic policy, Shackle and even Kurt Godel - published in 'L'industria', a journal edited by F. Di Fenizio, and 'Metroeconomica', founded and edited by E. Fossati.

${ }^{34} \mathrm{~F}$. Caffè, who didn't edit any journal, made an extensive use of translations to provide Italian students and also the general public with accessible versions of foreign economic thought

${ }^{35}$ Other books, such as Rey (1967) and the work done in conjunction with the attempt to lay down a framework for the indicative planning schemes prepared by the central government applied some of the principles of the discipline, specifically those of the theory of economic policy.
} 
Graziani, Vinci, but with greater attention to social choice and positive economic policy: Balducci Candela, 1991 (later Balducci, Candela, Scorcu, 2001, 2002), Acocella (1994, 1999) and Cagliozzi (1994). By including a positive approach in addition to the normative one, these books complemented the 'normative' theory of economic policy, thus completing the set of ingredients that can be ideally thought of constituting the discipline of economic policy. Some of these books also introduced the idea of economic policy as a game and discussed the implications on it of reputation, credibility and rules. ${ }^{36}$

Some of the Italian books that had developed and complemented the 'Scandinavian-Dutch' approach to economic policy were translated into English and other foreign languages (such as Chinese, Polish, Croatian) and enter now the syllabus of some tertiary-level courses abroad ${ }^{37}$. Notwithstanding this, the approach has apparently failed to develop abroad at the same time when it was practically abandoned in the countries of origin of its 'core'.

\section{WHY A LIMITED IMPACT IN EUROPE (AND ELSEWHERE)?}

Thus, the idea of economic policy as a discipline starting from welfare economics and social choice, including the normative and positive theory of economic policy and then dealing with specific policies and targets, with institutional and historical mediations before applying economic analysis, did not survive in the countries of origin and did not pass over to other countries. This is apparently strange. I offer four possible explanations that could jointly explain this setback:

1. The specificity of circumstances favouring the emergence and flourishing of the discipline in Scandinavia, the Netherlands and Italy. After all, these countries shared a common feature distinguishing them from other European countries: the weight and the left-wing orientation of the 'intelligencija' as well as of the political parties supporting the governments or of the strong opposition parties and institutions (such as trade unions) together with the idea that public happiness should be served by a visible hand. To this we should add another circumstance for Italy: an idealistic epistemological attitude of the Italian scientific community, the importance of the Marxist and Catholic credos - which are both pro-government - and the relevance of civil society. In order to explain why the idea of economic policy did not survive or pass over to other countries reference could be made not only to the absence of features similar to those just listed, but also to the strength of bureaucracy (including the status of the central bank) in some countries. This may 'insulate policy from various political pressures, although it may also limit the influence of outside economic theorists over policy'

\footnotetext{
${ }^{36}$ In addition to the books already cited, Persson, Tabellini (1990) dealt with issues of credibility and reputations that were familiar after the Lucas critique and Barro, Gordon (1983). To my knowledge the idea of policymaking as the interaction of governmental action with that of major private institutions was already in Caffè (1966), but he didn't express it in detailed and formal terms.

${ }^{37}$ This was the case for, e.g., Acocella $(1994,1999)$.
} 
(Pekkarinen, 1988: 5), which could explain why a theory of economic policy did not develop in France and Germany.

2. The rise and spread of the Anglo-Saxon school of thought, which has taken the lead over (other) national schools and traditions since the 1960s and has now led to a rather homogeneous literature, using the same language (English), the same methodology and building economic models based on similar visions and methodologies. This was due partly to a natural generational change and partly to the enhanced possibilities for circulating people and exchanging ideas that have favoured economic and cultural globalization in the last four to five decades. The flourishing Scandinavian and Dutch schools slowly disappeared as the impact of cultural globalization on smaller countries was quicker and higher ${ }^{38}$. It is natural that this homogeneity has been reached at the cost of taking national specificities out of the realm of analysis; it is not so natural that policy applications to solve specific issues in a given context follow after analysis with scarce reference to history and institutions, which is sometimes due to uncritical understanding of the respective contents of economic analysis and policy. ${ }^{39}$

3. The negative attitude of mainstream Anglo-Saxon thinking towards active policy intervention, which matured in the two decades since the end of the 1960s; we refer in particular to: the introduction of the expectation-augmented Phillips curve and the assertion of a vertical long-run curve (Phelps, 1967; Friedman, 1968); fiscal policy neutrality in the presence of ultra-rationality (Barro, 1974), monetary policy neutrality with rational expectations (Sargent, Wallace, 1975); generalized policy neutrality under rational expectations (Lucas, 1976), timeinconsistency and the need for rules rather than discretionary public action (Kydland, Prescott, 1977; Barro, Gordon, 1983); need for an independent conservative central banker (Bade, Parkin, 1978; Rogoff, 1985, and others); emergence of various positions and 'schools' stressing the limitations of a theory, such as the 'classical' theory of economic policy, that ignores the identity of policymakers, their political and personal objectives, and thus the numerous

\footnotetext{
${ }^{38}$ Kærgård, Sandelin and Sæther (2008) cite the influence of K. H. Borch, who was recruited to the Norwegian School of Economics and Business Administration as a professor of insurance from 1963 and urged his students to pursue doctoral studies in North America, thus weakening the influence of the Oslo School in Norwegian economics and politics. Other factors leading to the decline of the Oslo school are indicated by Eriksen, Hanisch and Sæther (2008). The disappearance of the tracts of the Swedish school due to globalisation of economic analysis along the lines dictated by the Anglo-Saxon schools is explained by Dixit, Honkapohja and Solow (1992). Dealing specifically with Sweden, but with implicit reference also to other countries, Jonung (2013) points out the attractions and the constraints of the younger generation of Swedish economists that make them publish in English, prefer occupations in North American universities and disregard policy issues and applications of theoretical thought. Jonung's analysis applies to Italy and to other countries too. To be fair, Siven (1985) explains the end of the Stockholm school as due in particular to the methodology of the school ('disinterest for equilibrium analysis, a preference for casuistic analysis, and

lack of instruments for analyzing the questions posed by the School itself'; see Siven, 1985: 592).

${ }^{39}$ Economic policy is not even listed as a subject in the Journal of Economic Literature system of classification and only 'macroeconomic policy' appears as a subcategory..
} 
agency problems arising in public governance (e.g. Downs, 1957; Tullock, 1965; Niskanen, 1971; Nordhaus, 1975; Hibbs, 1977; Alesina, 1987; Alesina, Tabellini, 1990; Persson, Tabellini, 2000).

4. The absence of theoretical advances in crucial areas of economics such as the theory of economic policy, after its practical demise as an effect of the Lucas critique.

The first and second explanations cannot be dealt with in more detail here as they require specific further investigations not only for the countries we have referred to, but also for others. In the next section we briefly review the last two explanations.

7. PRE-CONDITIONS FOR THE EXISTENCE OF ECONOMIC POLICY AS A DISCIPLINE AND THE FOUNDATIONS OF ITS 'CORE'

Any analytical discipline cannot be conceived if some minimal conditions are not satisfied, in particular in so far as the abstract pre-conditions for its existence are absent or insufficient or defective. In the case of economic policy there should be no 'vital' deficiencies in what we called its 'core'.

In the case of economic policy, the first such pre-condition has to do with recognition of existence of market failures. Other pre-conditions refer to the possibility or necessity of supplementing (or substituting) market decisions (as an institution expressing people's preferences) with consistent and effective public action.

In the period we are referring to now, no theoretical or practical objection was raised against market failures. By contrast, as already said, Akerlof (1970) added to the cases of market failures by introducing asymmetric information.

By contrast, logical and empirical objections were moved to the other preconditions as an effect of the innovations introduced in the two decades after mid1960s. Some such objections contributed to develop parts of economic policy and generated new fields of inquiry. Some others have been fatal until recently to survival of economic policy as an autonomous discipline and have contributed to its decline, while supporting the theoretical orientations of the Anglo-Saxon schools, referred to in the previous section.

The most awkward part of objections to the content of economic policy dealt with government failures. I divide them into two types: those that can be called 'minor' failures, on the one hand, and 'vital' failures, on the other.

'Minor' failures indicate government failures that have been emphasized by the 'positive' approach to economic policy. Some criticisms of this kind had already been raised before 1967 and were enriched later by a copious literature. They stress important factors to be taken account of in practical policy together with a number of other institutional and historical features characterizing the country in question and must certainly be part of the discipline when policy action is to be devised in practice. These objections can be dealt partly with in analytical terms similar to some of those referred to 'market failures' (asymmetric information). 
By 'vital' failures we refer instead to two objections: the impossibility of taking people's preferences as a reference for public action, underlined by Arrow (1951) and 'radical' objections to effectiveness of public action of the kind raised by Lucas (1976).

Let us refer to both in turn. After Arrow's contribution, a number of economists showed that his 'vital' objection to the possibility of deriving a social welfare function could be healed in much more (theoretically) acceptable ways than were the remedies that had been provided by Bergson (1938) and Samuelson (1938) and followed by Frisch (1957), which suggested to refer such function directly to politicians in charge. This suggestion, in fact, delegated to political science and practice finding proper solutions to devising democratic institutions. already mentioned in section $4 .^{40}$ These were indicated by Sen (1970) and later investigations, that added to the 'possibilities' to construct social welfare orderings or social ordering functions that had been indicated by Sen. ${ }^{41}$ More specifically, they are addressed by an ancillary discipline that has emerged in the more recent decades from previous studies, i.e. implementation theory ${ }^{42}$. This takes the incentive problem to the forefront of analysis and heavily relies on game theory, thus to some extent dealing also with some of the 'minor' problems raised by asymmetric information. These advances thus make the first part of the core of economic policy, i.e. the logic of economic policy, well founded.

We deal now with the 'radical' objections concerning the effectiveness of economic policy. These are essentially due to introduction of expectations, in particular the assumption of rational expectations. Some of these objections tended to negate the effectiveness of policy action even in the absence of agency issues. In their weakest form they constrained public policy into a Nessus shirt by prescribing a rather rigid set of rules. Stronger versions of this kind of criticism negated any active role to public policy in conflict with the conduct of private agents.

Until recently, these problems have been longly unaddressed, thus contributing in a decisive way to the decline of economic policy as an autonomous discipline. However, advances in the decade or so have shown that most statements of policy neutrality and policy prescriptions of the 1970s and 1980s were unfounded or of minor relevance. In more details, there have been advances reversing or appreciably mitigating such statements and prescriptions in the following crucial areas: the limited practical relevance of surprise effects, recognized by Lucas (1996: 679) himself; the irrelevance of many critiques to the 'classical' theory of economic policy (in particular, Tinbergen's 'golden rule' about conditions to be satisfied for the government to control the economy and pursue its targets) based on rational expectations (Blinder, 1998; Acocella, Di Bartolomeo, Hughes Hallett,

\footnotetext{
40 This could be conceived only as a practical shortcut, eluding some theoretical difficulties, but Bergson's suggestion was motivated by the need to avoid value judgments in scientific propositions.

${ }_{41}$ See, e.g., Arrow, Sen, Suzumura (1997, 2002, 2011), Moulin (1988), Dryzek, List (2003), Bossert, Weymark (2008).

${ }^{42}$ See, e.g., Jackson (2001), Maskin, Sjostrom (2002), Fleurbaey, Maniquet (2011).
} 
2012); the theoretical and practical limits to time inconsistency and thus to related prescriptions of monetary policy rules that should replace discretionary action (Blinder, 1998: 56; Acocella, Di Bartolomeo, Hughes Hallett, 2012); existence of a long-run non vertical Phillips curve (Hughes Hallett, 2000; Graham, Snower, 2008; Benigno, Ricci, 2011; Acocella, Di Bartolomeo, Tirelli, 2014a); the need for more active fiscal policy and regulation (especially with respect to financial markets and institutions) once some unrealistic assumptions of current models are ruled out; critique of the arguments put forward by Rogoff (1985) and Bade, Parkin (1978) advanced by Posen (1994) and Hayo (1998), which highlight that both political independence and inflation are the outcome of structural economic and social factors that make the central bank statutes have no impact on inflation); the need, in the presence of public transfers, of a rate of inflation higher than that close to zero rate prescribed by the consensus view of New Keynesian models (Acocella, Di Bartolomeo, Tirelli, 2014b). Of special interest are two issues raised in the literature that have inspired recent fiscal policy attitudes against the crisis in Europe and the idea of limited effectiveness of fiscal policy: on the one side, a widespread belief in the existence of a limit beyond which an increase in public debt would have negative consequences on growth (Reinhart, Rogoff, 2010; Checherita, Rother, 2010; Kumar, Woo, 2010); on the other side, the assertion of very low (in the limit, null, if one accepts Barro's proposition - see Barro, 1974) spending and tax multipliers. The former has recently been empirically questioned as a consequence of a Ph.D. investigation, but has received theoretical support by Checherita, Hughes Hallett, Rother (2010). The latter has passed through a long process of theoretical refinements, confutations and empirical evaluations, culminating in IMF (2010), De Grauwe (2011), Batini, Callegari and Melina (2012), De Long, Summers (2012), Blanchard, Leigh (2013), Semmler, Semmler (2013) which find higher values of the multipliers. The value of those multipliers in fact varies, being state dependent with respect to the conditions of the economy and monetary policy stance, but is seldom small or zero or even negative.

\section{CONCLUSIONS}

A discipline cannot survive and spread if some pre-conditions for its existence are not satisfied: existence of consistent bases that prove to be resistant to practical and, especially, theoretical objections. The flow of continuous innovations can attack some such bases. 'Minor' objections can be incorporated into the theory. Unaddressed objections to its core (i.e., 'vital' critiques) can be fatal for its existence and lead to a slow or fast decay. In our case, for a discipline such as economic policy, the decline might be accelerated by a simultaneous and interacting political wave counter to it, as can be the case in particular for social disciplines.

Economic policy in Scandinavia, the Netherlands and Italy was mainly built as a discipline by collecting various innovations introduced in different fields of economics, mathematics and statistics (in so far as the 'theory of economic policy' 
is concerned), in addition to political philosophy and political science (referring to welfare economics and social choice, i.e. the 'logic' of economic policy).

The discipline was constituted by its 'core' (the logic and the theory of economic policy), complemented by practical applications of both microeconomic and macroeconomic policies, highly sensible to institutional factors. Various parts of its core were the object of both 'minor' and 'vital' critiques concerning existence of government failures. 'Minor' critiques - most of them of a 'political economy' kind have been incorporated into the discipline. 'Vital' critiques have left the logic of economic policy untouched in so far as existence of market failures is concerned, thus setting, from this point of view, the stage for government intervention to cure such failures. 'Vital' objections have been directed instead mainly to existence of 'critical' government failures. They refer to: the impossibility of taking people's preferences as a reference for public action, stated by Arrow (1951) and 'radical' objections to effectiveness of public action of the kind raised by Lucas (1976). These critiques thus undermined the very possibility to heal market failures. These were confirmed (possibly enriched), but no follow up could ensue from the point of view of the action of an institution complementary or substitute of the market as could be the government. Thus the foundations of economic policy became shaky.

Critiques to the possibility of starting from individual preferences to build some kind of social welfare function or rule are 'vital' for a democratic society when public action aims at substituting or complementing the market as an institution expressing such preferences. For some time the suggestion devised by Bergson (1938) and Samuelson (1947) to refer to politicians in office stating collective preferences was accepted (see, e.g., Zeuthen, 1958; Frisch, 1970). That solution meant delegating to another discipline or, even worse, to reality finding a fundamental link between individual preferences and public action. However, the 'impossibility' objection was addressed, starting with Sen (1970), and has been largely overcome by a literature that is now developing in new interesting branches of the discipline such as implementation theory.

The other set of 'vital' critiques refers to the effectiveness of policy action in relation to the introduction of expectations - in particular, rational expectations into the analysis. When the power of Lucas critique defied part of the core of the discipline, i.e. the theory of economic policy, there was no possibility of maintaining the discipline as it had been designed in the Scandinavian countries, the Netherlands and Italy, possibly complemented and enriched by considerations of a 'political economy' kind. This latter set of critiques has not been addressed for a long time, which can contribute to explain the decline of economic policy as an autonomous discipline. To some extent, the very practical application of the discipline could have distracted its followers from further research and innovation, as it was certainly the case for the Stockholm school (Siven, 1985) and possibly also for the Oslo school (Eriksen, Hanisch and Sæther, 2008).

Now this part of the 'core' has not only been shown to be exempt from the critique, if policy action is designed in its proper strategic context, but also to be 
able to produce new interesting results in that context, in so far as existence, uniqueness or multiplicity of equilibria in the game are concerned. ${ }^{43}$

One could thus hope that economic policy as a consistent and autonomous discipline could gain momentum and challenge mainstream thought, which assigns a very limited role to it. This would avoid confining policy discussions to a few considerations following very abstract and sometimes unfounded theoretical reasoning that often neglect any institutional and historical element and lack the theoretical background deriving from the logic and the theory of economic policy. We are conscious however that this needs overcoming the power of some hysteresis in the development of economic thought that delays the dissemination of new ideas (Galbraith, 1987), which is not an easy task, at least in the short run.

\section{REFERENCES}

Acocella N. (1994), Fondamenti di politica economica. Valori e tecniche, Nuova Italia Scientifica, Roma (English tr.: Foundations of economic policy: Values and techniques, Cambridge University Press, 1998)

Acocella N. (1999), Politica economica e strategie aziendali, Carocci, Roma (English tr.: Economic policy in the age of globalisation, Cambridge University Press, 2005)

Acocella N. (2013), Teoria e pratica della politica economica: l'eredità del recente passato (Economic theory and policies: the inheritance of the recent past), Rivista di Storia Economica, 29: 223-48

Acocella N., G. Di Bartolomeo, A. Hughes Hallett (2012), The theory of economic policy in a strategic context, Cambridge University Press, Cambridge

Acocella N., G. Di Bartolomeo and P. Tirelli (2014a), Trend inflation, the labor market wedge, and the non-vertical Phillips curve, Journal of Policy Modeling, forthcoming

Acocella N., G. Di Bartolomeo and P. Tirelli (2014b), US trend inflation reinterpreted. The role of fiscal policies and time-varying nominal rigidities, Macroeconomic Dynamics, forthcoming

Akerlof G. (1970), The market for lemons. Uncertainty and the market mechanism, Quarterly Journal of Economics, 84: 488-500

Alesina, A. (1987). 'Macroeconomic policy in a two-party system as a repeated game', Quarterly Journal of Economics, 102: 651-678.

Alesina, A. and G. Tabellini (1990). 'A positive theory of fiscal deficits and government debt', Review of Economic Studies, 57: 403-14.

Arnon A. (2011), Monetary theory and policy from Hume and Smith to Wicksell: Money, credit and the economy, Cambridge University Press, Cambridge

Arrow K. J. (1950), A difficulty in the concept of social welfare, 'The Journal of Political Economy', 58: 328-46, Italian tr. in Caffè (1956b)

Arrow K. J. (1951), Social choice and individual values, Wiley and Son, New York

43 Acocella, Di Bartolomeo, Hughes Hallett (2012). It may be of interest to notice that the authors of this book are economists trained in the tradition of the classical theory of economic policy, who are working or have worked either in Italy or in the Netherlands. 
Arrow K. J., A. K. Sen, K. Suzumura, ed. (1997), Social choice re-examined, 2 voll. St. Martin's Press, New York

Arrow K. J., A. K. Sen, K. Suzumura, ed. (2002), Handbook of social choice and welfare, 1 vol, , Elsevier-North Holland, Amsterdam

Arrow K. J., A. K. Sen, K. Suzumura, ed, (2011), Handbook of Social Choice and Welfare, 2 vol., Elsevier-North Holland, Amsterdam

Bade R., M. Parkin (1978), Central bank laws and monetary policies: A preliminary investigation. The Australian monetary system in the 1970's, in M. Porter (ed.), The Australian Monetary System in the 1970s, Clayton, Monash University

Balducci R., G. Candela (1991), Teoria della politica economica, La Nuova Italia Scientifica, Roma, 2 vols.

Balducci R., G. Candela G., A. E. Scorcu (2001), Introduzione alla politica economica, Zanichelli, Bologna

Balducci R., G. Candela, A. E. Scorcu (2002), Teoria della politica economica. Modelli dinamici e stocastici, Zanichelli, Bologna

Barone E. (1908), II ministro della produzione nello stato collettivista, Giornale degli economisti, Sept.: 267-293 (English transl. As an appendix to Hayek F.A. (ed.), Collectivist economic planning, London, Routledge, 1935, pp. 245-290)

Barro, R. (1974). Are Government Bonds Net Wealth?, Journal of Political Economy, 82: 1095-1118

Barro, R. J., D. Gordon (1983), Rules, Discretion and Reputation in a Model of Monetary Policy, Journal of Monetary Economics, 12: 101-121

Bastiat, F. (1850), Harmonies économiques, Guillaumin, Paris

Batini N., G. Callegari and G. Melina (2012), Successful austerity in the United States, Europe and Japan, IMF W.P. 190, July

Bator F. (1958), The anatomy of market failure, Quarterly Journal of Economics, 72: 35179

Benigno P., L. A. Ricci (2011), The inflation-output trade-off with downward wage rigidities, American Economic Review, 101(4): 1436-66

Berardi D. (1894), La dottrina politico-economica di F. Ferrara, Giornale degli Economisti, IX, 9, pp. 225-265; 10, pp. 331-375

Bergson A. (1938), A re-examination of some aspects of welfare economics, Quarterly Journal of Economics, 52: 310-34 (published under the pseudonym of A. Burk), Italian tr. in Caffè (1956b)

Bjerkholt O. (1998), Interaction between model builders and policy makers in the Norwegian tradition, Economic Modelling, 15: 317-339

Bjerkholt O. (2005), Markets, models and planning: the Norwegian experience, Department of Economics,

University of Oslo, Memorandum No 14

Blanchard, O. J., D. Leigh (2013), Growth Forecast Errors and Fiscal Multipliers, IMF Working Paper No. 13/1, January

Blinder A.S. (1998), Central banking in theory and in practice, Cambridge, Mass.: MIT Press 
Bossert W., J. A. Weymark (2008), Social choice (new developments)," The New Palgrave Dictionary of Economics, 2nd Edition

Boulding K. E. (1958), Principles of economic policy, Prentice-Hall, Englewood Cliffs

Buchanan J.M. (1960), La scienza delle finanze'. The Italian tradition in fiscal theory, in J. M. Buchanan

Fiscal theory and political economy. Selected essays, Chapel Hill, University of North Carolina Press, pp. 24-74.

Buchanan J. M. (1975), The limits of liberty: Between anarchy and Leviathan, Chicago University Press, Chicago

Caffè F. (1953), Vecchi e nuovi indirizzi nelle indagini sull'economia del benessere, Tecnica Grafica, Roma

Caffè F. (1956a), Economia del benessere, in C. Napoleoni (ed.), Dizionario di economia politica, Ed. di Comunità, Milano

Caffè (1956b) (ed.), Saggi sulla moderna economia del benessere, Boringhieri, Torino

Caffè F. (1966), Politica economica. Sistematica e tecniche di analisi, vol. I, Boringhieri, Torino

Caffè F. (1970), Politica economica. Problemi economici interni, vol. II, Boringhieri, Torino

Cagliozzi R. (1994), Profili delle lezioni di politica economica, Liguori, Napoli

Carlson B., Jonung L. (2006), Knut Wicksell, Gustav Cassel, Eli Heckscher, Bertil Ohlin and Gunnar

Myrdal on the Role of the Economist in Public Debate, Econ Journal Watch, 3(3): 511-550

Carlson B., Jonung L. (2013), Ohlin on the Great depression, Knut Wicksell Working Paper 9

Checherita C., P. Rother (2010), The impact of high and growing government debt on economic growth an empirical investigation for the euro area ECB W. P. 1237

Checherita-Westphal C., A. Hughes Hallett, P. Rother (2014), Fiscal sustainability using growth-maximising debt targets, Applied Economics, Vol. 46 (6)

D'Antonio M., A. Graziani, S. Vinci (1972), Problemi e metodi di politica economica, Liguori, Napoli; 2nd ed., Cooperativa editrice Economia e commercio, Napoli, 1974

D'Antonio M., A. Graziani, S. Vinci (1979), Problemi e metodi di politica economica, 3rd ed., vol.1: Aspetti di metodo. Gli interventi di breve periodo, Liguori, Napoli

Dardi M. (2010), Marshall on welfare, or: the 'utilitarian' meets the 'evolver', European Journal of The History of Economic Thought, 17: 405-437

De Long B., L. H. Summers (2012), Fiscal Policy in a depressed economy, mimeo, March 20

De Grauwe P. (2011), A less punishing, more forgiving approach to the debt crisis in the eurozone, Ceps policy brief, no. 230

De Viti De Marco A. (1888), II carattere teorico dell'economia finanziaria, Pasqualucci, Roma

De Viti De Marco A. (1934), Principi di economia finanziaria, Einaudi, Torino (English tr.: First Principles of Public Finance, Jonathan Cape-Harcourt Brace \& Co., New York)

Di Fenizio F. (various years), Le leggi dell'economia; vol.1: II metodo dell'economia politica e della politica economica, L'industria, Milano, 1957; vol.2: II sistema economico, i grandi attori e i flussi di reddito, L'industria, Milano, 1958; vol.3: La funzione del consumo, 
L'industria, Milano, 1958; vol.4: Diagnosi, previsioni, politiche congiunturali in Italia, Isco, Roma, 1958; vol.5: La programmazione globale in Italia, Isco, Roma, 1962

Dixit, A. K., Honkapohja, S. and Solow, R. M. (1992), Swedish Economics in the 1980s. In Economics in Sweden: an Evaluation of Swedish Research in Economics, ed. Lars Engwall, London and New York: Routledge

Downs, A. (1957). An economic theory of good decision-making in democracy, New York: Harper \& Row.

Dryzek J. S., C. List (2003), Social choice theory and deliberative democracy: A reconciliation, British Journal of Political Science, 33(1): 1-28

Einaudi L. (1934), Preface to De Viti De Marco A. (1934)

Eriksen, I., T. J. Hanisch and A. Sæther (2008), The Rise and Fall of the Oslo School, Nordic Journal of Political Economy

Erixon L. (2011), Formalizing a new approach to economic policy - Bent Hansen, Gosta Rehn and the Swedish model, mimeo

Ferrara F. (1859), Prefazione a (Preface to) C. Dunoyer, in Opere complete di Francesco Ferrara, vol.5, De Luca, Roma, 1961

Fleurbaey M., Maniquet F. (2011), A theory of fairness and social welfare, Cambridge University Press, Cambridge

Fontana Russo L. (1902), I trattati di commercio e l'economia nazionale, Soc. ed. Dante Alighieri, Roma

Fontana Russo L. (1935), Corso di politica economica generale e corporativa, Cremonese, Roma

Franchini Stappo A. (1955), Studi sulla teoria macroeconomica della congiuntura, Società editrice universitaria, Firenze

Friedman, M. (1968). The Role of Monetary Policy, 'American Economic Review', 58: 1-17

Frisch, R. (1949). A memorandum on price-wage-tax subsidy policies as instruments in maintaining optimal employment, UN Document E (CN1/Dub 2), New York, reprinted as Memorandum fra Universitets Socialøkonomiske Institutt, Oslo, 1953

Frisch, R. (1950), L'emploi des modèles pour l'élaboration d'une politique économique rationnelle, 'Revue d'Économie Politique', 60: 474-498; 601-634

Frisch R. (1957), Numerical determination of a quadratic preference function for use in macroeconomic programming, Memorandum fra Universitets Socialøkonomiske Institutt, Oslo, No. 14, reprinted in Studies in honour of Gustavo Del Vecchio, 'Giornale degli Economisti e Annali di Economia', 1961, 1: 43-83

Frisch R. (1970), From utopian theory to practical applications: The case of econometrics, Lecture to the memory of Alfred Nobel, June 17, in A. Lindbeck, ed., Nobel Lectures, Economics 1969-1980, World Scientific Publishing Co., Singapore, 1992

Galbraith J. K. (1987), Economics in perspective. A critical history, Houghton Mifflin Co., Boston

Graham L., D.J. Snower (2008), Hyperbolic discounting and the Phillips Curve, 'Journal of Money, Credit and Banking', 40: 427-448

Grampp W.D. (2000), What did Smith mean by the invisible hand?,' Journal of Political Economy', 108: 441-65

Hansen, B. (1958), The economic theory of fiscal policy, Allen \& Unwin, London, first published in Swedish in 1955 
Harrod R. F. (1938), Scope and method of economics, 'Economic Journal', 48 (191): 383412

Hayek F. (1960), The Constitution of Liberty, University of Chicago Press, Chicago

Hayo B. (1998), Inflation culture, central bank independence and price stability, 'European Journal of Political Economy', 14: 241-63

Hibbs, D. A. (1977). 'Political parties and macroeconomic policy', American Political Science Review, 71: 1467-87.

Hicks J.R. (1939), The foundations of welfare economics, Economic Journal, 10: 215-28 (Italian tr. in Caffé, 1956b).

Hirai T. (2008), Keynes's theoretical development: from the Tract to the General theory, Routledge, London

Haavelmo T. (1956), Kryssløpsanalysen som teoretisk og som økonomisk-politisk instrument (Input-output analysis as a teoretical and economic policy instrument), Nationaløkonomisk Tidsskrift 94 (3), 114-121.

Haavelmo T. (1966), Modelltenkning og beslutningsprosess (Model thinking and decision making), Contribution on Sosialøkonomisk Samfunn's Fall Conference 1965, Sosialøkonomen 20 (2), 1-6.

Hotelling H. (1938), The general welfare in relation to problems of taxation and of railways and utility rates, 'Econometrica', 6: 242-69 (Italian tr.. in Caffé, 1956b)

Hughes Hallett A. (1989), Econometrics ad the theory of economic policy: The TinbergenTheil contributions 40 years on, 'Oxford Economic Papers', (41): 189-214

Hughes Hallett A. (2000), Aggregate Phillips curves are not always vertical: heterogeneity and mismatch in multiregion or multisector economies, 'Macroeconomic Dynamics', 4: 53446

International Monetary Fund (2010), Recovery, risk, and rebalancing, world economic and financial surveys, 'World Economic Outlook', October

Jackson M. O. (2001), A crash course in implementation theory, Social Choice and Welfare, 18: 655-708

Johansen L. (1977, 1978), Lectures on macroeconomic planning, 2 vol., North-Holland, Amsterdam

Jonung L., ed. (1991), The Stockholm school of economics revisited, Cambridge University Press, Cambridge

Jonung L. (2013), What can we learn from the Swedish approach to the crisis in the 1930s?, Dinner speech at the conference 'Towards a sustainable financial system', organized by the Swedish House of Finance, Global Utmaning and the Financial Market Group at the London School of Economics, Stockholm, September 12-13

Kærgård N. (2000), Osloskolen - særnorsk eller tidstypisk skandinavisk? (The Oslo School - particularly Norwegian or typical Scandinavian?), Nationaløkonomisk Tidsskrift 138: 329348

Kærgård N., B. Sandelin and A. Sæther (2008), Scandinavia, Economics in, in S. N. Durlauf and L. E. Blume (eds), The New Palgrave Dictionary of Economics, $2^{\text {nd }}$ ed., Palgrave Macmillan, London

Kaldor N. (1939), Welfare propositions and interpersonal comparison of utility, Economic Journal, 49: 549-52 (Italian tr. in Caffé, 1956b) 
Kapp K.W. (1950), The social costs of private enterprise, Harvard University Press, Cambridge, Mass

Keynes J.M. (1936), The general theory of employment, interest and money, Macmillan, London, repr. in The Collected Writings, vol. vii, Macmillan, London 1973

Kirschen E.S., L. Morissens (1964), Une exploration de la fonction de bien être en politique économique, 'Cahiers Économiques de Bruxelles', 22: 161-203

Kumar M.S., J. Woo (2010), Public debt and growth, IMF W.P. No. 10/174

Kydland, F. E. and E.C. Prescott (1977), Rules Rather than Discretion: The Inconsistency of Optimal Plans, Journal of Political Economy, 85: 473-492; repr. (1994) in Persson, J. and G. Tabellini, Vol. 1

Laidler D. (1999), Fabricating the Keynesian revolution, Cambridge University Press, Cambridge

Lindahl E. (1919), Die Gerechtigkeit der Besteuerung, Lund (partial Engl. Transl. as "Just Taxation. A Positive Solution," in R. A. Musgrave and A. T. Peacock (ed.), Classics in the Theory of Public Finance, London: Macmillan, 1958, pp. 168-76)

Little I.M.D. (1949), The foundations of welfare economics, 'Oxford Economic Papers', 1: 227-46 (Italian tr. in Caffé, 1956b)

Lombardini S. (1954), Fondamenti e problemi dell'economia del benessere, Giuffré, Milano Lucas, R. E. (1976), Econometric Policy Evaluation: A Critique, in K. Brunner and A. Meltzer (eds.), The Phillips Curve and Labour Markets, Carnegie-Rochester Conference Series on Public Policy, Amsterdam: North Holland, Vol. I

Lucas R. E. (1996), Nobel lecture: Monetary neutrality, 'Journal of Political Economy', 104: 661-682

Marglin S. (2008), The dismal science: How thinking like an economist undermines community, Harvard University Press, Cambridge, MA

Marrama V. (1948), Teoria e politica della piena occupazione, Edizioni italiane, Roma

Marrama V. (1961), Ciclo economico e politica anticiclica, Giannini, Napoli

Marrama V. (1962), Problemi e tecniche di programmazione economica, Cappelli, Rocca S. Casciano

Marshall A. (1890), Principles of economics, Macmillan, London

Maskin E., T. Sjostrom (2002), Implementation theory, Ch. 5 in Arrow, Sen, Suzumura (2002)

Mazzola U. ( 1890), I dati scientifici della finanza pubblica, Loescher e C., Roma (English tr. in Musgrave, Peacock, 1958)

Meade J.E. (1951), The theory on international economic policy, vol.1, The balance of payments, Oxford University Press

Meade J.E. (1955), The theory on international economic policy, vol.2, Trade and welfare, Oxford University Press

Mill J.S. (1848), Principles of political economy with some of their applications to social philosophy, John Parker, London

Moulin, H. (1988), Axioms of cooperative decision making, Cambridge University Press, Cambridge

Musgrave R. A., A. T. Peacock (1958), eds., Classics in the theory of public finance, Macmillan, London (2nd ed. 1994) 
Niskanen, W. (1971). Bureaucracy and representative government, Chicago: Aldine.

Nordhaus, W. D. (1975). 'The political business cycle', Review of Economic Studies, 42:169-90.

Nozick R. (1974), Anarchy, state and utopia, Basic Books, New York

Ohlin B. (1937), Some notes on the Stockholm theory of savings and investment I \& II, in 'Economic Journal', 1937, 47: 53-69. 221-40, reprinted in Readings in business cycle theory, London, 1950)

Palsson Syll L., Sandelin B (2001), The spread of Italian economic thought in Sweden 1750-1950, in P.F. Asso, From economists to economists. The International spread of Italian economic thought, Polistampa, Firenze

Pantaleoni M. (1883), Contributo alla teoria del riparto delle spese pubbliche, La rassegna italiana, 15 October, pp. 25-60; then in M. Pantaleoni, Scritti varii di economia, PalermoMilano 1904, pp. 49-110, and in Teorie della finanza pubblica, ed. by F. Volpi, Milano 1975, pp. 46-78 (selected parts are translated into English in Musgrave, Peacock, 1958, pp. 16-27)

Papi G.U. (1953) (ed.), Studi keynesiani, Giuffè, Milano

Pareto V. (1896-97), Cours d'économie politique, F. Rouge, Lausanne

Pareto V. (1906), Manuale di economia politica (reprinted by Nuova grafica Bizzarri, Rome, 1965); the English edition is: Manual of political economy, A. M. Kelley, New York, 1971, translated from the French edition of 1927 (first French ed., 1909)

Peck H. W. (1921), Review of 'Die Gerechtigkeit der Besteuerung' by Erik Lindahl, Political Science Quarterly, 36: 700-702

Pekkarinen J. (1988), Keynesianism and the Scandinavian models of economic policy, World institute for development economics research of the United Nations University, WP35, February

Persson T., G. Tabellini (1990), Macroeconomic policy, credibility and politics, Harwood Academic Publishers, Newark, 1990 (Italian tr. Politica macroeconomica. Le nuove teorie, Nuova Italia Scientifica, Roma, 1996)

Persson, T. and G. Tabellini (2000), Political economics: Explaining economic policy, Cambridge, MA: MIT Press.

Norton H.S (1966), Economic policy: Government and business, Charles E. Merrill Books, Columbus

Phelps E. S. (1967), Phillips curves, expectations of inflation and optimal unemployment over time, 'Economica', 34: 254-281

Pigou A.C. (1912), Wealth and welfare, Macmillan, London

Pigou A.C. (1920), The economics of welfare, Macmillan, London

Posen A. (1994), Is central bank independence the result of effective opposition to inflation? Evidence of endogenous monetary policy institutions, Harvard University, Cambridge Mass, mimeo

Reinhart C., K. Rogoff (2010), Growth in a time of debt, NBER W.P. 15639

Rey G.M. (1967), Regole ottimali per la politica economica (Optimal rules for economic policy), Giuffrè, Milano

Ricardo D. (1817), On the principles of political economy and taxation, ed. by P. Sraffa, Cambridge University Press, Cambridge, 1951 
Rogoff, K. (1985). Can international monetary policy coordination be counterproductive?, Journal of International Economics, 18: 199-217

Romani R. (2013), Minimal state theories and democracy in Europe: From the 1880s to Hayek, mimeo

Roncaglia A. (2005), II mito della mano invisibile (The mith of invisible hand), Laterza, Bari

Rothschild E. (2001), Economic sentiments: Adam Smith, Condorcet, and the Enlightenment, Harvard University Press, Cambridge, MA: pp. 138-42

Samuelson P. A. (1947), Foundations of Economic Analysis, ch. 8, Harvard University Press, Cambridge, Mass.

Sandelin B. (2001), The de-Germanisation of Swedish economics, History of Political Economy, 33: 517-539

Sargent T. J., N. Wallace (1975), Rational expectations, the optimal monetary instrument, and the optimal money supply rule, 'Journal of Political Economy', 83: 241-254

Scitovsky T. (1941), A note on welfare propositions in economics, Review of Economic Studies, 9: 77-88

Screpanti E., S. Zamagni (1989), Profilo di storia del pensiero economico, La Nuova Italia Scientifica, Roma (English tr.: An Outline of the History of Economic Thought, Clarendon Press, Oxford, 1993)

Semmler W., A. Semmler (2013), The macroeconomics of the fiscal consolidation in the European Union, mimeo, June 15

Sen A.K. (1970), Collective choice and social welfare, Holden Day, S. Francisco

Sidgwick H. (1883), Principles of political economy, Macmillan, London

Siven C.-H. (1985), The end of the Stockholm school, The Scandinavian Journal of Economics, 87: 577-593

Smith A. (1776), An inquiry into the nature and causes of the wealth of nations, Straham \& Cadell, London

Spencer, H. (1850), Social Statics. Williams and Norgate, London

Stiglitz J.E. (1986), Economics of the public sector, Norton \& Co. New York

Stone R., G. Croft-Murray (1959), Social Accounting and Economic Models, Bowes \& Bowes, London

Theil H. (1956), On the theory of economic policy, American Economic Review, 46: 360-66

Theil H. (1964), Optimal decision rules for government and industry, North Holland, Amsterdam.

Tinbergen J. (1935), Suggestions on quantitative business cycle theory, Econometrica, 3 : $241-51$

Tinbergen J. (1949), Du système de Pareto aux modèles modernes, Revue d'économie politique, 59: 642-652

Tinbergen J. (1952), On the theory of economic policy, North Holland, Amsterdam (Italian tr. edited by F. Di Fenizio: Sulla teoria della politica economica, Ed. L'Industria, Milano, 1955)

Tinbergen J. (1956), Economic policies. Principles and design, North Holland, Amsterdam

Tullock, G. (1965). The politics of bureaucracy, Washington, DC: Public Affairs Press.

Tullock G. (1976), The vote motive, The Institute of Economic Affairs, London (2nd ed. 2006) 
Van Eijk C. J., J. Sandee (1959), Quantitative determination of optimum economic policy, Econometrica, 27: 1-13

Walras (1874-1877), Eléments d'économie politique pure ou théorie de la richesse sociale, in A. and L. Walras, Oeuvres économiques complètes, vol. VIII, Economica, Paris

Walras (1898), Etudes d'économie politique appliquée, in A. and L. Walras, Oeuvres économiques complètes, vol. X, Economica, Paris

Watson D.S. (1960), Economic policy: Business and government, Houghton Mifflin, Boston Wicksell K. (1898), Geldzins und Güterpreise, Gustav Fischer, Jena (Interest and prices, English tr. by R. F. Kahn, Macmillan, London, 1936)

Wicksell K. (1934, 1935), Lectures on political economy, English tr., 2 vol., George Routledge and Sons, London, 1946

Zeuthen F. (1958), Videnskab og Velfaerd I okonomisk Politik, Gads Forlag, Copenaghen (Italian tr. edited by F. Caffè: Scienza e benessere nella politica economica (Science and welfare in economic policy), Boringhieri, Torino. 